\title{
The induction of obesity in rodents by means of monosodium glutamate
}

\author{
By J. BUNYAN, ELSPETH A. MURRELL AND P. P. SHAH \\ Beecham Pharmaceuticals, Research Division, Brockham Park, \\ Betchworth, Surrey $\mathrm{RH}_{3}{ }_{7} \mathrm{AY}$
}

(Received 28 November I974-Accepted 25 March 1975)

I. Monosodium glutamate (MSG) was administered by various methods to mice and rats of
various ages and the incidence of obesity was later measured.
2. Newborn mice were injected subcutaneously with $3 \mathrm{mg} \mathrm{MSG} / \mathrm{g}$ body-weight at $1,2,3$, 6,7 and $8 \mathrm{~d}$ of age; $16 \%$ died before weaning. Of the survivors, $90 \%$ or more became markedly obese. Mean carcass lipid content was increased by about $120 \%$ in both sexes at 20-30 weeks of age. In male mice, MSG treatment increased body-weight and epididymal fat pad weight, and greatly decreased adrenaline-stimulated lipolysis in isolated fat cells. Body-weight of females was not increased significantly. Food intake was not increased in either sex from weeks $I_{3}$ to 15 . Blood glucose level was not generally increased by MSG but some of the male mice had abnormally high values.

3. Obesity was not detected in the offspring of female mice that had received $100 \mathrm{~g} \mathrm{MSG} / \mathrm{kg}$ diet, either from 3 weeks before mating until weaning, or from the $14^{\text {th }}$ day of pregnancy until weaning.

4. Intraperitoneal injection of ro $\mathrm{mg} \mathrm{MSG/g}$ body-weight (in two doses) at weaning increased carcass lipid content in female mice by $34 \%$ by 23 weeks of age, but female rats were not affected.

5. The addition of $20 \mathrm{~g} \mathrm{MSG/1} \mathrm{to} \mathrm{the} \mathrm{drinking-water} \mathrm{from} \mathrm{weaning} \mathrm{onwards} \mathrm{did} \mathrm{not} \mathrm{increase}$ carcass lipid content in female rats or mice.

6. The addition of $20 \mathrm{~g} \mathrm{MSG} / \mathrm{kg}$ diet from weaning onwards did not alter body-weight or carcass lipid content in male and female rats by 14 weeks of age.

7. The obesity induced in mice by MSG was not associated with hyperphagia, unlike genetic obesity and obesity induced by gold thioglucose (GTG).

8. All types of mouse studied, obese and lean, had essentially the same linear relationship between carcass water content and carcass lipid content.

9. Although MSG-obese mice could not readily be differentiated from normal mice by the increase in body-weight, which was only about ro \% compared to 50-120\% for genetic and GTG-induced obesity, the proposed schedule of injections in the newborn was almost $100 \%$ reliable in inducing a high extent of adiposity.

Monosodium glutamate (MSG), injected subcutaneously in massive doses, induced severe retinal damage in newborn mice (Lucas \& Newhouse, 1957; Cohen, 1967). After this work, Olney ( 1969 ) discovered neuronal necrosis in the hypothalamic region of the brain of MSG-treated mice. He also found that the growth of these mice was stunted and that they developed obesity without hyperphagia. The females became sterile. Olney (1969) also induced acute brain lesions in adult mice with larger doses of MSG, but he did not observe whether they too became obese.

Djazayery \& Miller (1973) and Djazayery, Miller \& Stock (1973) had only moderate success in inducing obesity in weanling female mice by intraperitoneal injections of $5 \mathrm{mg} \mathrm{MSG/g} \mathrm{body-weight.} \mathrm{Prenatal} \mathrm{treatment} \mathrm{was} \mathrm{used} \mathrm{by} \mathrm{Adkins,} \mathrm{Lynch} \mathrm{\&} \mathrm{Lewis}$ (1971). They added $100 \mathrm{~g} \mathrm{MSG/kg}$ to the stock maternity diet of female rats from 3 weeks before mating, continuing throughout gestation and lactation. Marked 
Table I. Expt I. Dosage schedule and survival rates of newborn mice (born to primagravida CFLP* mice) given subcutaneous injections of monosodium glutamate (MSG)†

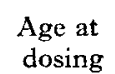

(d)

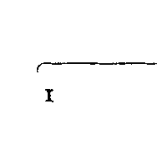

(2.

Batch no.

34

Dose (mg MSG/g body-wt)

$\begin{array}{rrrrrrrr}\circ \S & - & - & - & - & - & - & - \\ 1 & - & - & - & 3 & 3 & 3 & - \\ 2 & 2 \cdot 2 & 3 & 3.5 & 3 & 3 & 3 & - \\ 3 & 2 \cdot 5 & - & 3 \cdot 5 & 3 & 3 & 3 & - \\ 4 & 2 \cdot 8 & - & - & - & - & - & - \\ 5 & 3 \cdot 2 & 6 & 4 & - & - & - \\ 6 & 3 \cdot 4 & - & - & 6 & 3 & 3 & - \\ 7 & 3 \cdot 6 & - & - & 6 & 3 & 3 & - \\ 8 & 3 \cdot 8 & 6 & - & 6 & 3 & 3 & - \\ 9 & 4 \cdot 0 & - & - & - & - & - & - \\ 10 & 4 \cdot 2 & - & - & - & - & -\end{array}$

No. of surviving pups

\begin{tabular}{|c|c|c|c|c|c|c|c|}
\hline \\
\hline 0 & 67 & $4 I$ & $5^{8}$ & I 53 & 152 & ${ }^{1} 5^{I}$ & 45 \\
\hline 3 & - & - & - & 145 & r 38 & r 46 & - \\
\hline 8 & $5^{6}$ & 32 & I6 & 54 & г 38 & 143 & - \\
\hline 23 & 44 & 2,5 & 12 & 45 & 1329 & I27 & 40 \\
\hline
\end{tabular}

* Supplied by Carworth-Europe, Alconbury, Huntingdon, Cambs., UK.

$+\mathrm{MSG}$ in $0.15 \mathrm{M}-\mathrm{NaCl}$ solution; each mouse received $0.01 \mathrm{ml} / \mathrm{g}$ body-wt, injected in the subscapular region.

$\ddagger$ About two-thirds of each litter was left undosed to provide control mice for comparative purposes.

$\S$ Day of birth.

II Excluding one surviving runt.

If Excluding two surviving runts.

biochemical changes, including an increase in plasma cholesterol, were detected in the offspring at $7 \mathrm{~d}$ of age, but no survivors were retained for observation of later development of obesity.

The experiments reported in this paper were designed to study the incidence and characteristics of obesity in mice and rats given MSG by various methods at various ages, in comparison with mice with gold thioglucose (GTG)-induced obesity and genetic obesity.

\section{EXPERIMENTAL}

\section{Animal experiments}

Animals and diets. Mice (strain CFLP) and rats (strain CFY) were obtained from Carworth-Europe (Alconbury, Huntingdon, Cambs., UK). Genetically obese mice (strain $\mathrm{C}_{57} \mathrm{Bl} / 6 \mathrm{~J}(\mathrm{ob}-\mathrm{ob})$ ) and normal litter-mates were obtained from The Jackson Laboratory, Maine, USA, at about ro weeks of age. Genetically obese mice and normal litter-mates of the Aston strain were bred in our laboratories. Breeding animals of this strain were kindly given to us by Dr A. Beloff-Chain of Imperial College, London, from a colony derived from the strain maintained at the Aston University, Birmingham. The breeding diet for rats and mice (Oxoid Ltd, Southwark 
Bridge Road, London SEr $9 \mathrm{HF}$ ) was obtained before pasteurization and pelleting, and was used as the stock diet. This diet contained $(/ \mathrm{kg}) 205 \mathrm{~g}$ crude protein (nitrogen $\times 6.25), 38 \mathrm{~g}$ crude oil, $26 \mathrm{~g}$ crude fibre, $17.7 \mathrm{MJ}(4.23 \mathrm{Mcal})$ gross energy. All animals were housed four to ten/cage, except the breeding females which were caged individually, and provided with food and water $a d$ lib.

Expt I. Injections of MSG in newborn mice. Six batches of newborn pups of primagravida CFLP mice were injected subcutaneously in the subscapular region with MSG solution in $0.15 \mathrm{M}-\mathrm{NaCl}$, at the times and in amounts shown in Table $\mathrm{I}$. The volume of the dose was fixed at $0.0 \mathrm{Im} / \mathrm{g}$ body-weight. In the first two batches about onethird of each litter was left undosed to provide control mice for comparative purposes. The numbers of surviving mice were counted daily until weaning at $23 \mathrm{~d}$ of age. After weaning the mice were housed ten/cage and weighed every week. From the $13^{\text {th }}$ to the I $^{\text {th }}$ week the food intake of two cages of treated and of control mice was measured.

At 20 and 30 weeks, some of the injected mice and controls were killed for carcass analysis and for the measurement of lipolytic rates and blood glucose concentrations. The Lee index of obesity $(\sqrt[3]{\text { body-wt }}(\mathrm{g}) \div$ naso-anal length $(\mathrm{cm}))$ was estimated for the carcasses as described by Redding, Schally, Arimura \& Wakabayashi (197I).

Expt 2. Treatment of pregnant mice and preweaned offspring with dietary MSG. Twenty-five young breeding female CFLP mice were mated with CFLP males and then allocated at random to three groups with four (A), eleven (B) and ten (C) mice/ group. The mice of group $A$ received stock diet only throughout the experiment. For group B the stock diet was supplemented with Ioo $\mathrm{g}$ MSG/kg from 3 weeks before mating until the offspring were weaned. For group C, the same supplemented diet was given from the $14^{\text {th }}$ day of pregnancy until the offspring were weaned. The start of pregnancy was determined by vaginal smears. At 18 weeks of age, the offspring were killed and their carcasses were analysed for lipid content.

Expt 3. Treatment of weanling rats and mice with $M S G$. In this experiment, one treatment $(A)$ consisted of two intraperitoneal injections, $2 \mathrm{~h}$ apart, of $5 \mathrm{mg} \mathrm{MSG} / \mathrm{g}$ body-weight. A solution of MSG in $0.15 \mathrm{M}-\mathrm{NaCl}$ solution was used. Treatment $B$ consisted of adding $20 \mathrm{~g} \mathrm{MSG} / 1$ to the drinking-water from weaning onwards. Treatment $C$ consisted of adding $20 \mathrm{~g} \mathrm{MSG} / \mathrm{kg}$ to the stock diet from weaning onwards. Fifty-five female mice were allocated at random into groups of fifteen to twenty (see Table 5) to receive treatments $A$ or $B$, or no treatment. They were killed at 23 weeks of age. Sixty-seven female rats were similarly allocated to groups of twenty to twenty-seven to receive treatments $A$ and $B$ with controls receiving no treatment. They were killed at $\mathrm{x} 7$ weeks of age.

Treatment $C$ was administered to eight male rats and six female rats with similar numbers of male and female rats as untreated controls. These rats were killed at I4 weeks of age. All these rats and mice were analysed for carcass lipid content as an assessment of the incidence of obesity.

Expt 4. Genetically obese mice and GTG-obese mice. Obesity was induced in male CFLP mice of I 8-22 $\mathrm{g}$ body-weight by single intraperitoneal injections of GTG (Sigma Chemical Co., London), at the rate of $0.75 \mathrm{mg} / \mathrm{g}$ body-weight, in $0.15 \mathrm{M}-\mathrm{NaCl}$ 
solution (Shah, English \& Bunyan, 1972). In a typical experiment, the mean bodyweight of nine untreated mice was $35^{\circ} \cdot \mathrm{g}$ (SE $\mathrm{I}^{\cdot} 5 \mathrm{~g}$ ) after 8-10 weeks. At that time about one-third of the twenty-seven treated mice of the same litters had become obese and weighed $55^{\circ} 5 \mathrm{~g}$ (SE I.02 g). Eight male GTG-obese CFLP mice were killed at $2 \mathrm{I}$ weeks of age for carcass analysis.

Six male and six female genetically obese Aston mice and eight normal controls of each sex were killed at 18 weeks of age for analysis of carcass lipid content. Food intake had been assessed during the previous 3 weeks. The food intake of genetically obese $\mathrm{C}_{57} \mathrm{Bl} / 6 \mathrm{~J}$ mice was measured during the period 29-32 weeks of age, but corresponding values for control mice are not available. Twelve female obese mice and six non-obese litter-mates were killed for carcass analysis at 32 weeks of age. Four male genetically obese and eight lean $\mathrm{C}_{57} \mathrm{Bl} / 6 \mathrm{~J}$ mice were killed at 25 weeks of age for measurement of the weight of the epididymal fat pad and the extent of adrenaline-stimulated lipolysis.

Effects of obesity on carcass composition. The regression relationship between carcass lipid content and carcass water was studied in lean and obese mice of the $\mathrm{C}_{57} \mathrm{Bl} / 6 \mathrm{~J}$ and Aston strains and in normal and MSG-obese CFLP mice. Values were taken from experiments with controlled comparisons of lean and obese mice and also from experiments in which only obese mice were used.

\section{Analytical methods}

Carcass lipid and water content. Each carcass was chopped into small pieces and dried in a beaker at $105-110^{\circ}$ for $2 \mathrm{I} \mathrm{h}$. The contents of the beaker were washed into an extraction thimble with chloroform-methanol $(2: \mathrm{I}, \mathrm{v} / \mathrm{v})$ and extracted in a Soxhlet apparatus for $5 \mathrm{~h}$ with the same solvent. The solvent was removed by evaporation and both the lipid and the defatted dried carcass were dried at $105-110^{\circ}$ for $18 \mathrm{~h}$ and weighed. Each rat was treated similarly except that two $5 \mathrm{~g}$ samples of dried carcass were used for lipid extraction; the mean value was taken.

Carcass energy content. The high lipid content of the carcasses made it difficult to obtain representative samples of the original dried carcass. Therefore the energy contents of the carcass lipid and the lipid-free carcass were determined separately. Duplicate samples of about $0.7 \mathrm{~g}$ lipid-free carcass were pelleted, weighed again, and their energy contents estimated using the ballistic bomb calorimeter (A. Gallenkamp \& Co. Ltd, London EC2) described by Miller \& Payne (1959). Duplicate samples of $0.4 \mathrm{~g}$ carcass lipid were similarly treated. The calorimeter was calibrated using benzoic acid (analytical grade).

Carcass protein. Two $0.3 \mathrm{~g}$ samples of each dried, lipid-free carcass were analysed by the Kjeldahl method (Association of Official Agricultural Chemists, 1960).

Hormone-stimulated lipolysis. Lipolytic activity in isolated fat cells was estimated by the method described by Shah et al. (1972).

Blood glucose. Samples $(0.02 \mathrm{ml})$ of blood were taken from the tips of the tail and analysed by the glucose-oxidase method of Faulkner (1965), using an AutoAnalyzer (Technicon Instruments Co. Ltd, Basingstoke, Hants).

Statistical interpretation of the results. The significances of the differences in 
Expts 1 and 4 were assessed by Student's $t$ test. In Expts 2 and 3 , the results were analysed, separating the 'between-groups' variance from the 'within-groups' variance. The 'between-groups' variance was not significant and it was therefore pooled with the 'within-groups' variance to provide the estimate of error variance. The significances of treatment effects were assessed by the method of least significant differences.

\section{RESULTS}

\section{Expt I. Injections of MSG in newborn mice}

Table I gives the dose schedules used for six batches of newborn mice, and their survival rates. The schedule used for batch I was the scheme of Potts, Modrell \& Kingsbury ( 1960 ), as modified by Cohen ( 1967 ). Table 2 gives the carcass lipid values for mice from all batches except batches 3 and 5 .

In batch $\mathrm{I}$ the injections of MSG were not immediately toxic but only about twothirds of the mice survived to $23 \mathrm{~d}$ of age. For batch 2 the number of doses of MSG was smaller but the dose was increased to $6 \mathrm{mg} / \mathrm{g}$ body-weight and a similar survival rate was found. The dose schedule for batch 3 consisted of four somewhat higher early doses than those used by Potts et al. (1960). This schedule was not used again because so few of the mice survived. The dose schedule for batch 4 was designed to give nearly the same total dose as for batch I but spread over six doses up to day 8 . Heavy mortality occurred before day 8 . Reducing all six doses to $3 \mathrm{mg} / \mathrm{g}$ body-weight gave a satisfactory survival rate, as in batch $5(87 \%)$ and batch $6(84 \%)$.

Table 2 indicates that all the MSG-injected mice had greatly increased carcass lipid contents. Only batches I and 2 were strictly controlled and their lipid contents were greater than those of the undosed controls to a highly significant extent. As indicated in Table 2, some of the mice in batches 4 and 6 were treated with various drugs, not described here, which over all did not detract from the general picture of adiposity in these MSG-injected mice. However, the values for untreated mice are given separately from the combined values.

The incidence of obesity in the surviving young mice was very high. At 20 weeks of age, the highest values for carcass lipid contents in the controls were $266 \mathrm{~g} / \mathrm{kg}$ for the males and $337 \mathrm{~g} / \mathrm{kg}$ for females. Among the injected mice, the lowest male value, with one exception, was $336 \mathrm{~g} / \mathrm{kg}$ and the lowest female value was $378 \mathrm{~g} / \mathrm{kg}$. Of sixtyseven mice weaned from batches $I$ and 2 , sixty-three survived and a random sample of ten males and twenty-eight females (Table 2) were all obese.

Of forty-five mice weaned from batch 4 , forty-three were analysed and found to be obese, by the criterion of excessive adiposity. Thus the 'success rate' of the treatment applied to batch 4 was at least $96 \%$. The 'success rate' in batch 6 was more difficult to assess. Of the 127 mice weaned, 108 that definitely 'felt fat' were selected for analysis. Of these, 107 proved to be obese (Table 2). However, this estimated 'success rate' of $84 \%$ (IO7 obese from a total of 127 weaned) may have been too low, because some of the nineteen mice that did not 'feel fat' may in fact have been obese.

Values for batch 5 mice are not quoted because subsequently they received a 


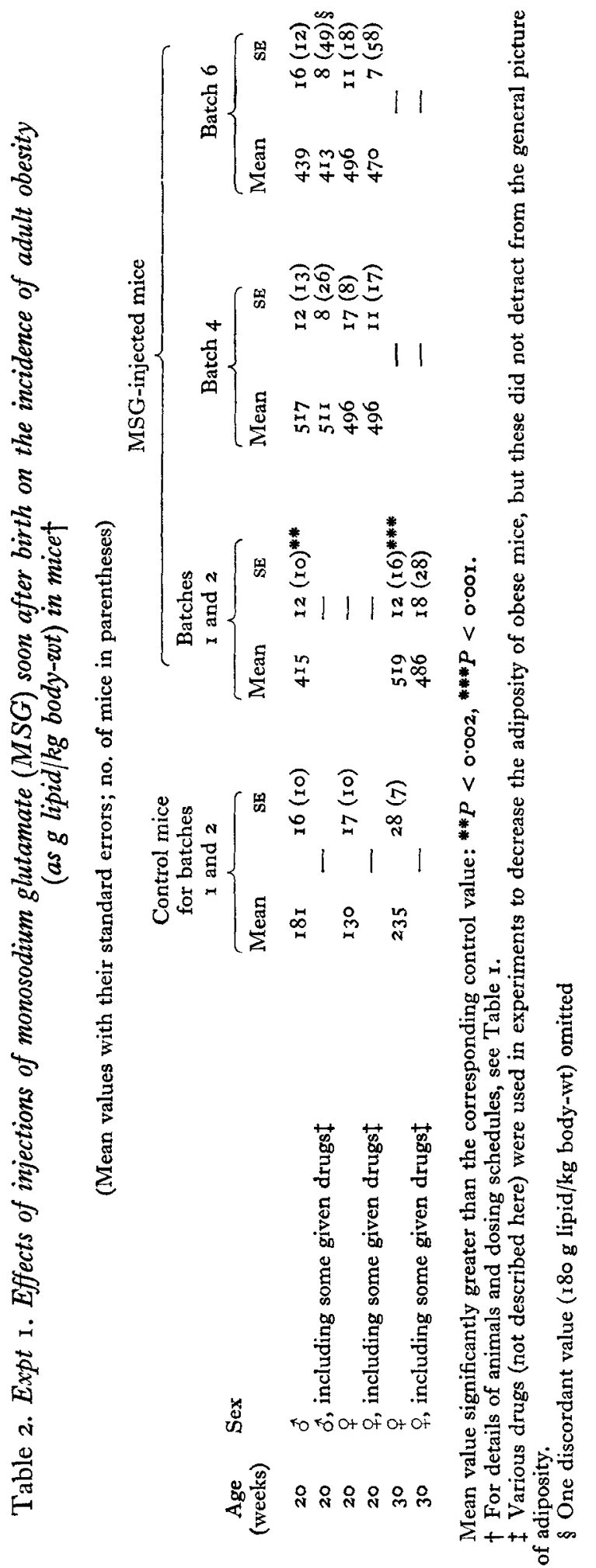


Table 3. Expt 1. Effects of injections of monosodium glutamate (MSG) soon after birth on biological and biochemical characteristics of mice $\dagger$

(Mean values with their standard errors; no. of mice in parentheses, except where indicated)

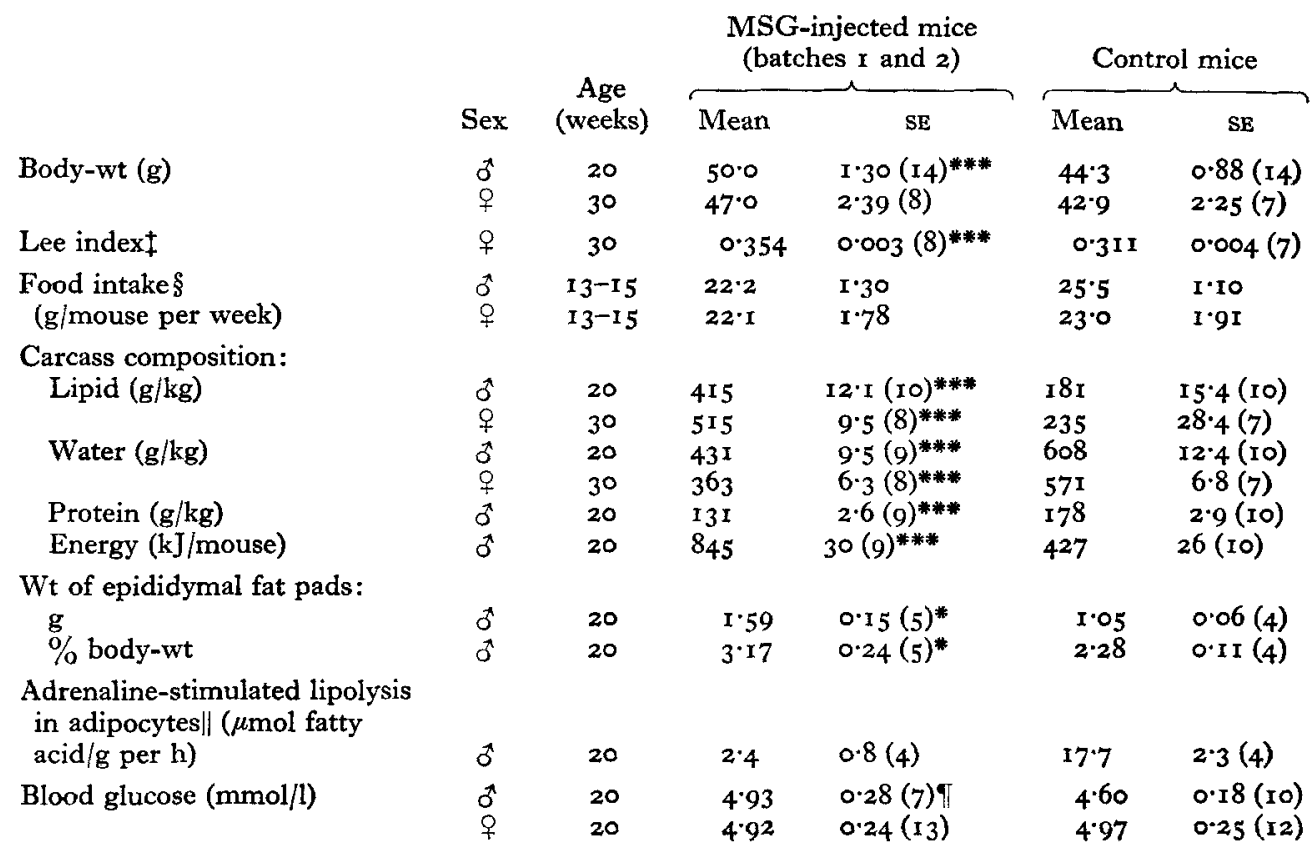

Mean value significantly different from the corresponding control value: $* P<0.05$, *** $<0.00$ r.

+ For details of animals and dosing schedules, see Table $\mathrm{I}$.

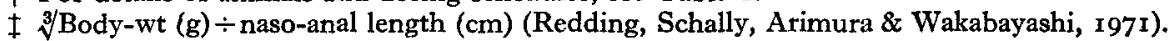

$\S$ Mean weekly food intakes of two groups of ten mice measured over 2 weeks.

II $5 \mu \mathrm{mol}$ Adrenaline/l incubation mixture; for details, see Shah, English \& Bunyan (1972).

if Also three higher values of $7 \cdot 7,8 \cdot 0$ and $\mathrm{I} \cdot 0 \mathrm{mmol} / \mathrm{l}$.

vitamin-deficient diet, but the incidence of adiposity was very high. Too few of batch 3 survived for further experiments.

Further characteristics of the MSG-obese mice of batches $I$ and 2 are given in Table 3 . The males but not the females were significantly heavier than their corresponding controls. The Lee index was calculated for females and it clearly indicated their obesity. Most of the carcasses were analysed, and the results indicated a significant increase in lipid content and significant decreases in water and protein contents in the MSG-obese mice. As expected, the obesity was associated with a higher value for total carcass energy. In five obese males the epididymal fat pads were dissected out and weighed; the actual and relative weights were greater than those for the controls. The hormone-stimulated lipolysis rate in epididymal fat cells was very much decreased compared to controls. Ideally the comparison should be of lipolytic activities per cell rather than per $g$ tissue. However, the activity per cell must have been greatly decreased in the obese mouse because the 7 -fold decrease in activity per $g$ tissue cannot be explained by the 'dilution effect' of the $50 \%$ excess fat in the fat pad. In general the blood glucose concentrations were similar in obese and control 
Table 4. Expt 2. Effects of dietary monosodium.glutamate (MSG) on the development of obesity in mice

(Adult male and female CFLP mice (supplied by Carworth-Europe, Alconbury, Huntingdon, Cambs., UK) were mated and the offspring were weaned at 4 weeks of age. Mean values with their standard errors; no. of analyses in parentheses)

\begin{tabular}{|c|c|c|c|c|c|c|c|c|}
\hline \multirow[b]{4}{*}{ Group } & \multirow[b]{4}{*}{ Treatment of dams } & \multicolumn{5}{|c|}{ Progeny } & & \\
\hline & & \multirow[b]{3}{*}{ Sex } & \multirow{3}{*}{$\begin{array}{l}\text { At birth } \\
\text { Total } \\
\text { no. }\end{array}$} & \multicolumn{5}{|c|}{ At 18 weeks of age } \\
\hline & & & & \multirow{2}{*}{$\begin{array}{l}\text { No. of } \\
\text { survivors }\end{array}$} & \multicolumn{2}{|c|}{ Body-wt (g) } & \multicolumn{2}{|c|}{$\begin{array}{c}\text { Carcass lipid } \\
(\mathrm{g} / \mathrm{kg})\end{array}$} \\
\hline & & & & & Mean & $\mathrm{SE}$ & Mean & SE \\
\hline A & Stock diet* throughout & $\begin{array}{l}0 \\
0 \\
0\end{array}$ & $\begin{array}{r}5 \\
I I\end{array}$ & $\begin{array}{r}5 \\
10\end{array}$ & $\begin{array}{l}44 \cdot 8 \\
38 \cdot 8\end{array}$ & $\begin{array}{l}2 \cdot 13(5) \\
1 \cdot 26(10)\end{array}$ & $\begin{array}{l}157 \\
178\end{array}$ & $\begin{array}{l}19 \cdot 0(5) \\
31 \cdot 0(5)\end{array}$ \\
\hline B & $\begin{array}{l}\text { Stock diet* + Ioo g } \\
\text { MSG/kg diet from } \\
3 \text { weeks before mating } \\
\text { until weaning }\end{array}$ & $\begin{array}{l}0 \\
q \\
q\end{array}$ & $\begin{array}{l}33 \\
3^{\circ}\end{array}$ & $\begin{array}{l}3 \circ \\
3^{\circ}\end{array}$ & $\begin{array}{l}40 \cdot 4 \\
34 \cdot 2\end{array}$ & $\begin{array}{l}0.76(30) \\
0.64(30)\end{array}$ & $\begin{array}{l}158 \\
\text { r } 18\end{array}$ & $\begin{array}{l}15.3(7) \\
13.9(12)\end{array}$ \\
\hline C & $\begin{array}{l}\text { Stock diet* + roo g } \\
\text { MSG/kg diet from } \\
\text { r } 4 \text { th day of pregnancy } \\
\text { until weaning }\end{array}$ & $\begin{array}{l}0 \\
0 \\
+1\end{array}$ & $\begin{array}{l}34 \\
34\end{array}$ & $\begin{array}{l}28 \\
32\end{array}$ & $\begin{array}{l}41 \cdot 8 \\
34 \cdot 2\end{array}$ & $\begin{array}{l}0.71(28) \\
0.74(32)\end{array}$ & $\begin{array}{l}\text { Ir3 } \\
130\end{array}$ & $\begin{array}{l}26.9(7) \\
9.0(12)\end{array}$ \\
\hline
\end{tabular}

* Breeding diet for rats and mice (Oxoid Ltd, Southwark Btidge Road, London SEI 9HF) obtained before pasteurization and pelleting.

mice. However, among the ten males studied there were three abnormally high values: $7 \cdot 7,8 \cdot 0$ and $\mathrm{Ir} \cdot 0 \mathrm{mmol} / \mathrm{l}$.

Food intake was not increased in the obese mice at $13-15$ weeks of age.

Expt 2. Treatment of pregnant mice and preweaned offspring with dietary MSG

MSG did not induce obesity when given in the diet, whether the mice received it from 3 weeks before mating or from the 14 th day of pregnancy (Table 4). All values for carcass lipid content were in the normal range when the mice were studied at I8 weeks of age.

\section{Expt 3. Treatment of weanling rats and mice with $M S G$}

As shown in Table 5, the intraperitoneal injection of ro $\mathrm{mg} \mathrm{MSG/g}$ body-weight induced a significant increase in carcass lipid content in mice but not in rats. However, the change in mice was only $34 \%$. The dose of MSG was given in two injections separated by an interval of $2 \mathrm{~h}$, because a single dose of $10 \mathrm{mg} / \mathrm{g}$ body-weight proved toxic.

Addition of MSG to the drinking-water after weaning failed to increase the carcass lipid content in mice or rats. Adding MSG to the diet of weanling rats was also ineffective. 
Vol. 35

है

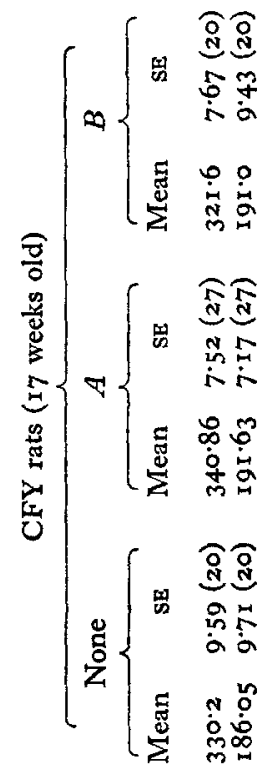

宽

डี है

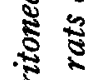

空.

is

胥.

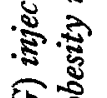

50

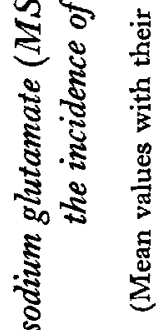

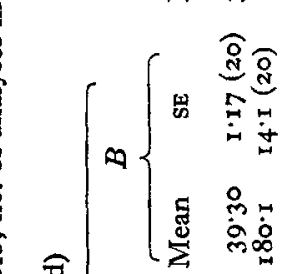

궁

[象兽

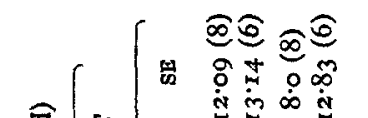

กั่

8

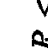

\&

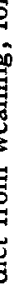

$\frac{0}{0}$

0

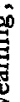

g

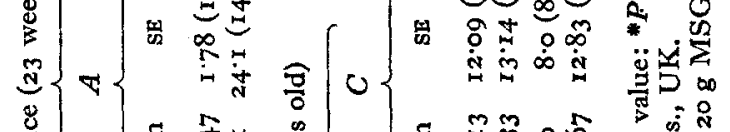

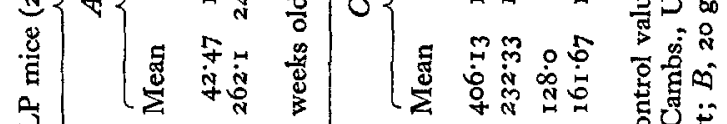

空

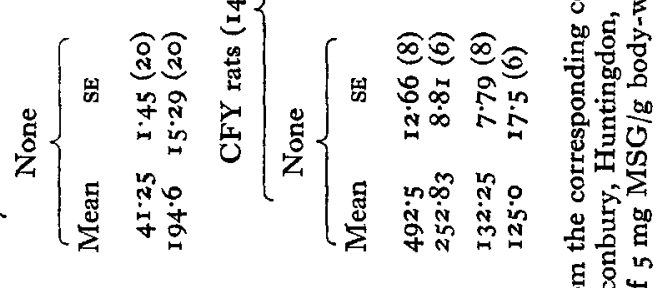

总 ot ot

峞 root root

速安

o

造

范

密吉

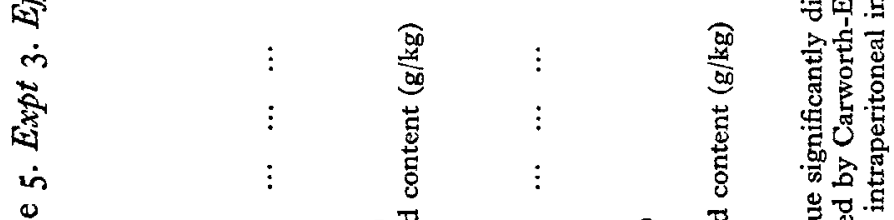

造

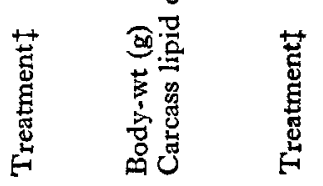

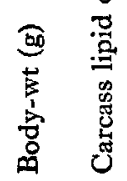

产竞

卷语 


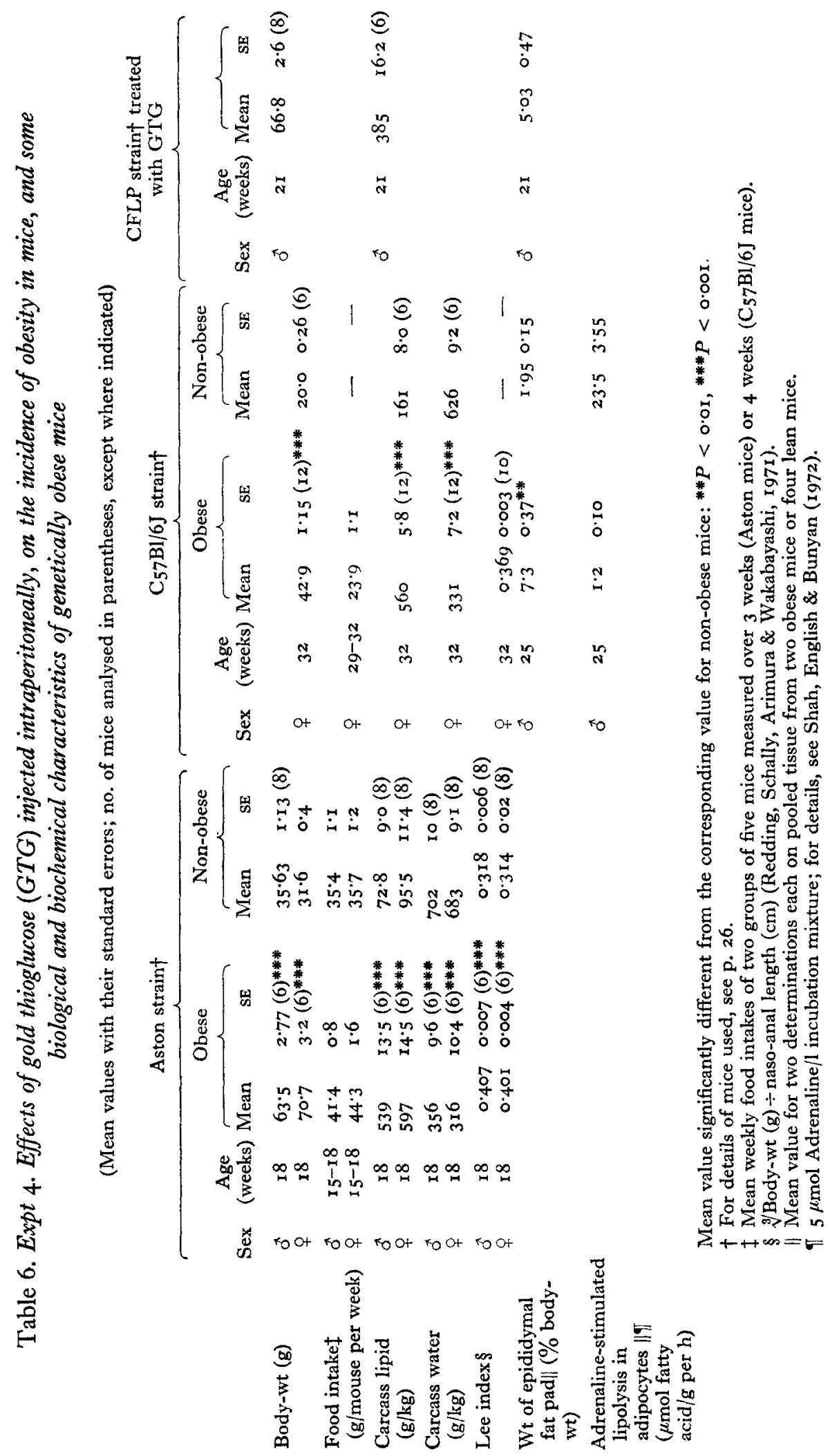




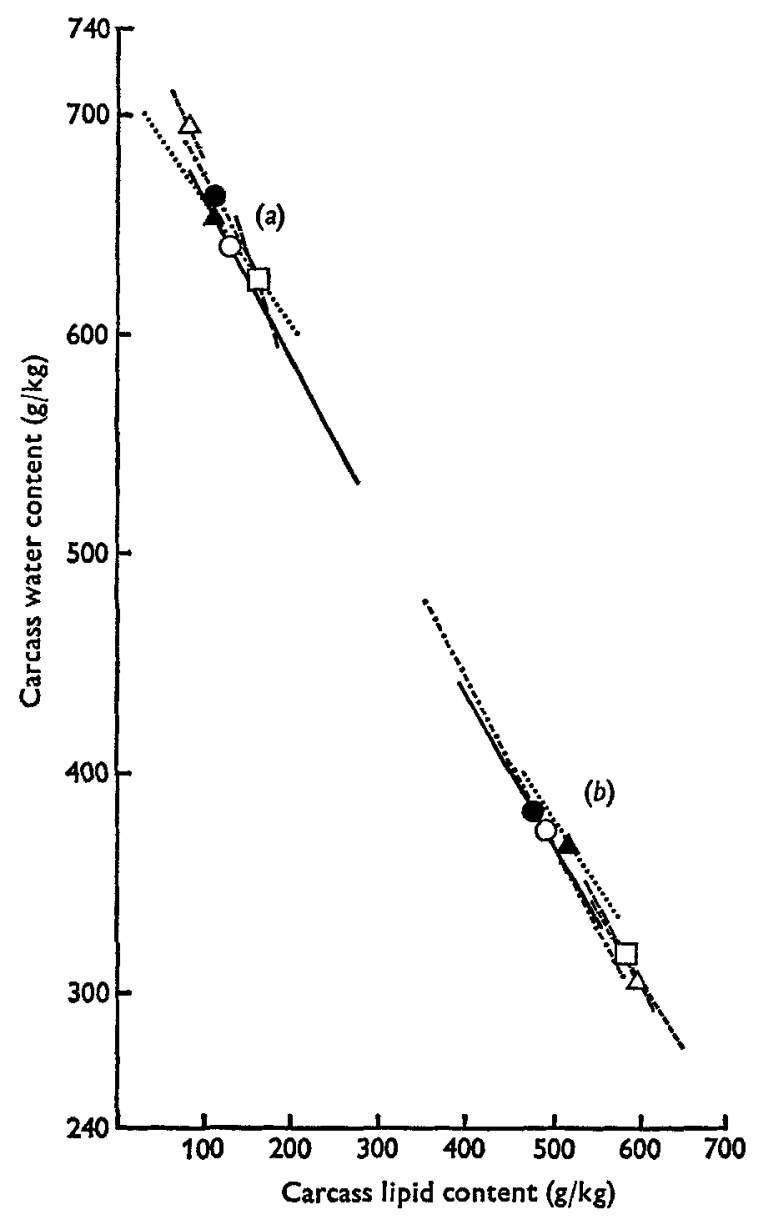

Fig. 1. Relationship between carcass water $(\mathrm{g} / \mathrm{kg})(Y)$ and carcass lipid $(\mathrm{g} / \mathrm{kg})(X)$ in $(a)$ lean and $(b)$ obese mice: ( $\longrightarrow-$ ), CFLP strain (supplied by Carworth-Europe, Alconbury, Huntington, Cambs., UK) $q$; (-- $-\triangle----)$, Aston strain (for details, see p. 26) $q$; (- - - ), $\mathrm{C}_{57} \mathrm{Bl} / 6 \mathrm{~J}$ strain (supplied by The Jackson Laboratory, Maine, USA) $(-\cdot \cdot \cdots \cdot)$, CFLP strain $\sigma^{*} ;(\ldots . . .$.$) , Aston strain \partial^{*}$. In the Aston and $\mathrm{C}_{57} \mathrm{Bl} / 6 \mathrm{~J}$ mice, the obesity was genetic; in the CFLP mice, it was induced by monosodium glutamate. The mid-point of each set of values is indicated by the position of the appropriate symbol. Each line extends from the lowest to the highest carcass lipid value obtained. Regression equations were:

$$
\begin{aligned}
& \text { lean, CFLP o }(n \text { I0): } \quad Y=737.66-0.73955 X \quad(P<0.001) \text {, } \\
& \text { obese, CFLP } \&(n \text { I }): \quad \quad Y=722.24-0.70227 X \quad(P<0.001) \text {, } \\
& \text { lean, CFLP } \hat{x}(n \text { 13): } \quad Y=744.48-0.72036 X \quad(P<0.001) \text {, }
\end{aligned}
$$

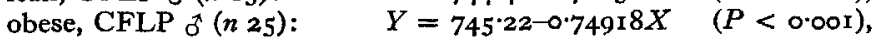

$$
\begin{aligned}
& \text { lean, Aston } q(n \text { 5): } \quad Y=766.86-0.87691 X \quad(P<0.01) \text {, } \\
& \text { obese, Aston }+(n \text { I7): } \quad Y=689.27-0.63590 X \quad(P<0.001) \text {, } \\
& \text { lean, Aston } \delta(n): \quad Y=724.02-0.5925 X \quad(P<0.01) \text {, } \\
& \text { obese, Aston ơ (ni5): } \quad Y=694.26-0.62617 X \quad(P<0.001) \text {, } \\
& \text { lean, } \mathrm{C}_{57} \mathrm{Bl} / 6 \mathrm{~J} \text { o }(n 6): \quad Y=808 \cdot 20-\mathrm{r} \cdot 1306 X \quad(P<0.00 \mathrm{r}) \text {, }
\end{aligned}
$$

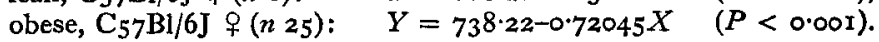




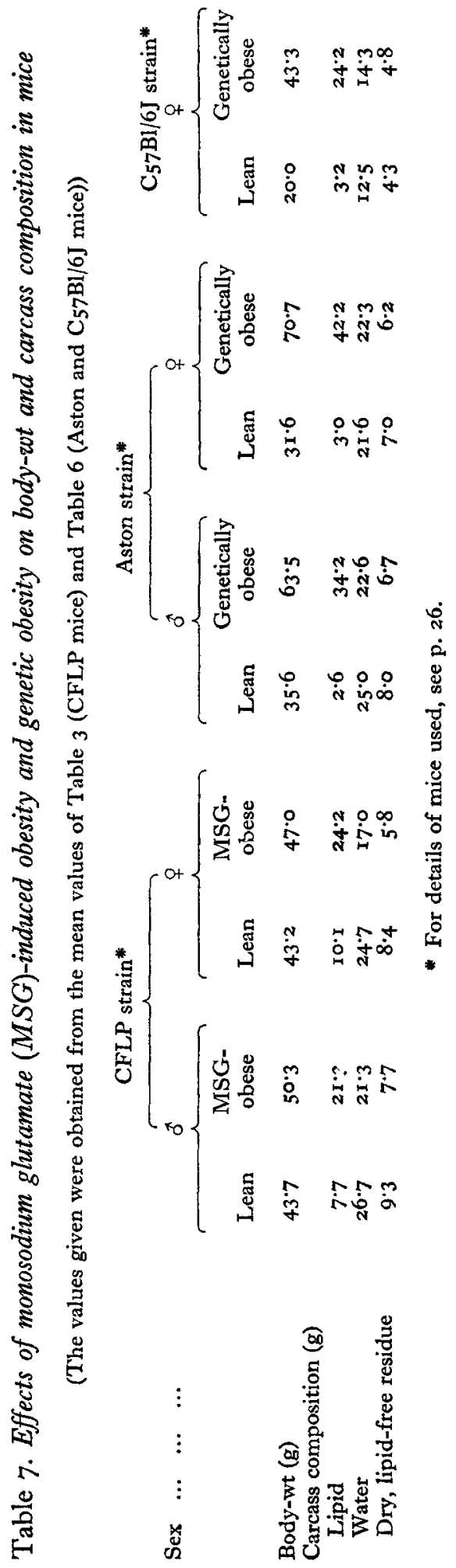




\section{Expt 4. Genetically obese and GTG-obese mice}

In the Aston strain, obese mice of both sexes were very much heavier than their non-obese litter-mates (Table 6). They ate more food and contained greatly increased amounts of lipid in the carcass, and also had an increased Lee index.

Obese females of the $\mathrm{C}_{57} \mathrm{Bl} / 6 \mathrm{~J}$ strain, although they were much smaller mice, paralleled the Aston strain in respect of the relative increase in body-weight and carcass lipid content. The epididymal fat pads of male $\mathrm{C}_{57} \mathrm{Bl} / 6 \mathrm{~J}$ obese mice were much heavier and the isolated fat cells had a greatly decreased rate of lipolysis in vitro. As discussed above, although lipolytic activity was not determined on a per cell basis, the activity per cell must have been decreased because the decrease per $g$ tissue was much greater than the increase in tissue weight. The values for the GTG-obese CFLP mice may be compared approximately with the male control CFLP mice described in Table 3. The increased body-weight, carcass lipid content and epididymal fat pad weight is quite clear.

\section{Effects of obesity on carcass composition}

A close relationship was found between carcass water and carcass lipid contents in lean and obese mice of both sexes, aged 8-3I weeks. No effect of age was noted over the range studied. The regression equations were all quite similar, as shown in Fig. I, suggesting that carcass water was replaced by lipid during the development of obesity. However, calculation of the actual weights of the various carcass components (Table 7) indicated a more complicated situation. In MSG-obese mice the large increase in lipid content was offset by smaller decreases in water and dry, lipid-free residue (proteins and minerals), leaving only a moderate increase in body-weight. Compared with these MSG-obese mice, the genetically-obese Aston strain were found to have a much larger increase in body-weight and lipid, a smaller decrease, if any, in water, and a smaller decrease in dry, lipid-free residue. The smaller $\mathrm{C}_{57} \mathrm{Bl} / 6 \mathrm{~J}$ geneticallyobese mice differed from the Aston mice in having an increase in total body water and dry, lipid-free residue.

\section{DISCUSSION}

MSG is not the only amino acid salt to cause brain damage in infant mice. Olney \& Ho (I970) found that the arcuate nuclei of the hypothalamus were damaged when ro-r2-d-old mice were given orally $3 \mathrm{mg} \mathrm{MSG,} \mathrm{L-glutamic} \mathrm{acid,} \mathrm{monosodium}$ L-aspartate or L-cysteine/g body-weight. Equivalent amounts of $\mathrm{NaCl}$ had no effect. Olney \& Ho (I970) commented that these three amino acids form a select group of 'neuroexcitatory' amino acids that can depolarize nerve membranes (Curtis \& Crawford, 1969).

The brain lesions detected by Olney (I969) in newborn mice injected with MSG were mainly in the preoptic and arcuate nuclei of the hypothalamus, together with scattered neurones within the median eminence. On the other hand, the ventromedial nuclei, in which the 'satiety centre' is thought to be located (Debons, Krimsky, From \& Cloutier, 1970), were spared. Debons et al. (1970) found that the 'satiety 
centre' suffers necrotic lesions when mice are injected with GTG and it is also known that electrolytic destruction of the ventromedial portion of the hypothalamus leads to obesity. Hyperphagia is a characteristic of GTG-obesity and of obesity induced by electrolysis but is largely absent from the development of MSG-obesity. These considerations suggest that the arcuate nucleus, which is damaged by MSG, may function in a regulatory manner towards fat metabolism (Olney, r969).

Some authors (Adamo \& Ratner, I970; Oser, Carson, Vogen \& Cox, 197I) have not fully confirmed the findings of Olney (1969). However, Burde, Schainker \& Kayes (1971) have explained the discrepancies as being due to differences in technique and have fully confirmed the cellular pathology in both rats and mice. The experiments reported here have confirmed the work of Olney (1969) in respect of the development of obesity in mice receiving MSG parenterally in the first ro $d$ of life. However, we found much smaller increases, if any, in body-weight in the obese animals. The strain difference may account for this.

Parenteral administration of MSG at weaning age produced adiposity in mice but not in rats. Addition of MSG to the drinking-water or diet from weaning onwards was unsuccessful. Young mice were also unaffected when the dams were given MSG in the diet. A similar failure to induce obesity by adding MSG to the diet was also reported by Prosky, O'Dell \& Johnson (1971).

The MSG-obese mouse resembles the genetically obese mouse in its greatly increased body lipid content and also in its greatly decreased rate of hormonestimulated lipolysis. The finding of high blood glucose values in a few MSG-obese mice at 20 weeks of age suggests that a transient hyperglycaemia may be a feature of the obesity, similar to that known to exist in the genetic type (Coleman \& Hummel, 1972).

Although repeated injections of MSG in newborn mice involve some technical difficulties, the method has advantages over the other methods of producing obesity in mice. As described above, a high proportion of the MSG-treated mice survive and become obese, whereas in the induction of GTG-obesity only about one-third of the mice eventually survive with obesity, there being a heavy mortality at the time of injection and only a partial incidence of obesity in the survivors. Production of the genetically obese mouse is complicated by such factors as the sterility of the obese females, the need to restrict the food intake of the obese males in order to preserve their fertility, and the low incidence $(25 \%)$ of obesity among the offspring of heterozygous mating pairs. Unlike the GTG-obese mouse and the genetically obese mouse, the MSG-obese mouse is not readily distinguished from its non-obese litter-mates by an increase in body-weight. However, most of the MSG-obese mice can be identified by their 'fatty feel', due to their greatly increased adiposity, and by their changed body shape. In addition, the dose schedule proposed has induced obesity in almost all the animals of successive batches.

The authors wish to thank Mr M. V. Sennitt for the blood glucose determinations, Miss R. J. Castle for the carcass analyses and $\mathrm{Mr} \mathrm{D}$. Hiley for care of the experimental animals. Thanks are also due to Mr B. Hunter of Huntingdon Research Centre, Huntingdon, for most of the injections. 


\section{REFERENCES}

Adamo, N. J. \& Ratner, A. (1970). Science, N.Y. 169, 673.

Adkins, J. S., Lynch, J. F. \& Lewis, L. M. (1971). Fedn Proc. Fedn Am. Socs exp. Biol. 30, 460 Abstr. Association of Official Agricultural Chemists (1960). Official Methods of Analysis, 9th ed., p. 12. Washington, DC: Association of Official Agricultural Chemists.

Burde, R. M., Schainker, B. \& Kayes, J. (1971). Nature, Lond. 233, 58.

Cohen, A. I. (1967). Am. F. Anat. 120, 319.

Coleman, D. L. \& Hummel, K. P. (1972). Diabetologia 8, 49 Abstr.

Curtis, D. R. \& Crawford, J. M. (r969). A. Rev. Pharmac. 9, 209.

Debons, A. F., Krimsky, I., From, A. \& Cloutier, R. J. (1970). Am. I. Physiol. 219, 1403.

Djazayery, A. \& Miller, D. S. (1973). Proc. Nutr. Soc. 32, 3oA.

Djazayery, A., Miller, D. S. \& Stock, M. J. (1973). Proc. Nutr. Soc. 32, 3 I A.

Faulkner, D. E. (1965). Analyst, Lond. 90, 736.

Lucas, D. R. \& Newhouse, J. P. (I957). A.M.A. Archs Ophthal. 58, I93.

Miller, D. S. \& Payne, P. R. (1959). Br. F. Nutr. 13, 501.

Olney, J. W. (1969). Science, N.Y. 164, 719.

Olney, J. W. \& Ho, O.-L. (1970). Nature, Lond. 227, 609.

Oser, B. L., Carson, S., Vogen, E. E. \& Cox, G. E. (1971). Nature, Lond. 229, 4I r.

Potts, A. M., Modrell, K. W. \& Kingsbury, C. (1960). Am. F. Ophthal. 50, 900.

Prosky, L., O'Dell, R. G. \& Johnson, O. C. (I97I). Fedn Proc. Fedn Am. Socs exp. Biol. 30, 460 Abstr. Redding, T. W., Schally, A. V., Arimura, A. \& Wakabayashi, I. (1971). Neuroendocrinology 8, 245.

Shah, P. P., English, P. D. \& Bunyan, J. (1972). Biochim. biophys. Acta 270, 86. 